\title{
Management of Financial Education at Madrasah Tsanawiyah (MTs) Negeri 1 Musi Banyuasin
}

\author{
Muhammad Yamin ${ }^{1 *)}$, Edi Harapan², Rohana ${ }^{2}$ \\ ${ }^{1}$ MAN 1 Musi Banyuasin, South of Sumatera, Indonesia \\ ${ }^{2}$ Universitas PGRI Palembang, Indonesia \\ *Corresponding author. Email: artantisari@gmail.com
}

\begin{abstract}
The purpose of this study was to identify and describe the process of supervising education financing at MTs Negeri 1 Musi Banyuasin. This study used qualitative research methods. Data collection techniques used observation, interviews, documentation, and triangulation. Data analysis techniques are data collection, data condensation, data presentation, and drawing conclusions. The results of this study can be concluded that the education financing supervision process has steps, namely checking, checking, matching, inspecting, controlling, regulating, and preventing before failure occurs. With the supervisory rules in accordance with the procedures contained in the technical guidelines, namely inherent supervision is carried out by the head of the madrasah as the power user of the budget, internal functional supervision is carried out by the inspectorate of the ministry of religion, supervision by the provincial Financial and Development Supervisory Agency (BPKP), supervision by the Financial Supervisory Agency (BPK) and supervision by the community.
\end{abstract}

Keywords: Management, Financing, Education

\section{INTRODUCTION}

Education is a major element in human resource development, both formally and informally. Through education, humans can become more moral and can know things that were never known before [1]. Meanwhile, education is a system that affects each other and depends on achieving educational goals in accordance with what is expected together [2].

The ideal education as referred to in Law Number 20 of 2003 concerning the National Education System, namely the many components of education which constitute a-complete and integrated system to drive learning to humans perfectly, so that the achievement of predetermined educational goals can run as that was planned. One of these components is education financing.

Harapan [3] states that education financing is all costs that are sacrificed in order to follow the educational process, both formally, informally, and informally. Education financing is an important thing in its proper management according to the funding requirements needed in education administration. In other words, without financial support, the educational process cannot run [1]. Managing education financing is one of the main factors in the aspect of education because it greatly determines the success of an education
Education financing is regulated in Government Regulation Number 19 of 2005 concerning National Education Standards in Chapter I Article 1 Paragraph (10) and Chapter IX Article 62 Paragraph (1) to Paragraph (5) concerning the scope of the financing standard. The general provisions regarding Financing Standards in Article 1 appear narrower than Article 62, namely the financing standards in Article 1 include standards that regulate the components and the amount of operating costs of an educational unit valid for one year.

Meanwhile, it is explained in the Regulation of the Minister of Religion of the Republic of Indonesia Number 66 of 2016 concerning the Second Amendment to the Regulation of the Minister of Religion Number 90 of 2013 concerning the Implementation of Madrasah Education Chapter XIV of Article 62 of Financing.

The cost of education is the total expenditure, both in the form of money and non-money, as an expression of the sense of responsibility of all parties (society, parents, and government) for educational development, so that the educational goals that are aspired to be achieved can be achieved efficiently and effectively, which must be continued extracted from various sources, maintained, consolidated, and ordered administratively [5]. 
To carry out education financing, Handoko [4] state that management is a process of planning, organizing, directing and supervising the efforts of organizational members and the use of other organizational resources in order to achieve predetermined organizational goals.

Term management which refers to the process of coordinating and integrating work activities so that they can be completed efficiently and effectively through other people [6]. Meanwhile, Kristiawan [7] state that management is the science and art of regulating, controlling, communicating and utilizing all resources in the organization by utilizing management functions (Planning, Organizing, Actuating, Controlling, so, that the organization can achieve goals effectively and efficiently.

Robbins and Judge [8] combine management functions into four parts, namely planning, organizing, leadership, and controlling. Furthermore, G. R. Terry, argues that management has a function abbreviated as P.O.A.C., namely Planning (planning), Organizing (organizing), Actuating (mobilizing, actualizing), Control (supervision) [9].

Supervision in general can be defined as an organizational way of realizing effective and efficient performance, and further supporting the realization of the organization's vision and mission [9]. Control (controlling) is the discovery and application of methods and equipment to ensure that the plan has been implemented in accordance with what has been determined [4].

Furthermore, it is said that supervision is associated with controlling, fostering and straightening efforts as an effort to control quality in a broad sense. With effective supervision, the wheels of the organization, implementation of plans, policies, and efforts to control quality can be implemented properly. Supervision is an administrative function where every administrator ensures that what is done is what they want [10].

Saefullah [11] defines controlling or supervision and control is one of the management functions in terms of conducting assessments, making corrections to everything that has been done by subordinates so that it can be directed to the right path in accordance with the objectives. Meanwhile, in Islamic education, supervision is a continuous monitoring process to ensure the implementation of consistent planning, both material and spiritual.

Supervision is an activity carried out to rectify things that are not straight, correct wrong and justify rights [11]. In more detail Saefullah [11] explains that the steps in supervision include: 1) checking, 2) checking, 3) matching, 4) inspecting, 5) controlling, 6) regulating, and 7) preventing before failure occurs.

Mufron [12] states the intent and purpose of supervision, namely: to find out whether the work is running smoothly or not, to correct mistakes made by employees, and to seek prevention so that the same mistakes do not occur again or the occurrence of mistakes. new, to find out whether the use of the budget that has been determined in planning is directed at the target and in accordance with what has been determined, to find out whether the implementation of financing is in accordance with the program (pose or level of implementation) as determined in the planning or not, to determine the results of the work compared to what has been stipulated in the plan (standard) and in addition, to find out whether the implementation of work is in accordance with predetermined procedures and policies.

Based on research conducted by Faijin [13] "Education Financing Management (Case Study at MTs Maslaku Huda Sluke)", that supervision functions to monitor all activities in the use of education budget financing, prevent mistakes, and prevent deviations.

Madrasah Tsanawiyah (MTs) Negeri 1 Musi Banyuasin is an example of a secondary education institution equivalent to a junior high school (SMP). From year to year the development of this Madrasah is very rapid and its existence is still recognized by the community, as evidenced by the large number of students who want to enter and register as madrasah students, from the data on the number of students for the 2019-2020 school year who were accepted as many as 288 , this number is far more. From the previous year, it means that the public's interest to send their children to Madrasah Tsanawiyah Negeri 1 Musi Banyuasin is very high.

Based on the results of preliminary observations before conducting further research, it can be seen from the physical buildings, such as the paint for each room in the madrasah, that they are always neat and beautiful. Another reason is that activities every Friday morning around 06.30-07.15 WIB before learning begins, namely reading surah yasin, sholawat, kultum, and prayer, carried out in the madrasa field represented by scheduled classes, reading short letters injuz 30, every Tuesday to Thursday conducted in the classroom before learning starts at around 07.00-07.15WIB each class of letters read differently and have been scheduled. Dhuha prayers and dzuhur prayers in congregation, carried out every Monday to Thursday by 2 classes that have been appointed or scheduled. Then extracurricular activities, one of which is the Tahfidz Qur'an, is carried out in the afternoon after school.

Therefore, madrasas have a very important role in the formation of a young generation of character and in the development of the generation of Indonesian Muslims, besides being competent in the fields of religion, academics, both science and social studies, and language. Madrasah are recognized as having advantages in shaping students with character, madrasas are able to produce students who are devout in religion, in addition to having skills in carrying out worship and reading the Al-Qur'an [14].

So, the management referred to in this paper is seen from the supervisory function on education financing, 
which is intended to identify and describe the process of monitoring education financing at MTs Negeri 1 Musi Banyuasin.

\section{METHODS}

This research uses qualitative methods, starting from conducting a preliminary study to determine the focus of the research as a problem limitation. After that, determine the problem in the form of questions that must be answered in this study. Then the researcher determined the data collection technique using observation, interview, documentation, and triangulation. Furthermore, the researcher determined the informants and made the interview instrument grid, interview guide, observation guide and documentation to be used as a benchmark in obtaining research data, then determined data analysis techniques, namely data collection, data condensation, data presentation, and drawing conclusions. Checking or verifying the data's validity, primarily by evaluating its credibility, transferability, dependability, and confirmability.

\section{RESULTS AND DISCUSSION}

The results of research observations on Education Financing Management at Madrasah Tsanawiyah (MTs) Negeri 1MusiBanyuasin, in terms of supervision, obtained data on the object under study are buildings, technical guidelines for BOS Madrasah 2019, Madrasah Activity and Budget Plans (RKAM) / Details of Working Paper Satker (RKKS), General Cash Book (BKU)and Cash Assistant Book, Tax Assistant Book, Bank Assistant Book, receipts and expenditures of BOS funds, reports on the realization of the use of funds for each source of funds, meeting data, minutes with the committee.

Based on these data, it is known that researchers in observing financing management that focus on controlling / controlling madrasas with the object being observed show that the observed conditions exist (evidence attached). Thus, education financing activities at Madrasah Tsanawiyah (MTs) Negeri 1 Musi Banyuasin in managing school operational assistance funds are in accordance with existing technical guidelines.

Broadly speaking, the documentation needed in the research entitled Management of Education Financing at MTs N 1 Musi Banyuasin in terms of controlling includes: madrasah profile, vision and mission of madrasah, organizational structure, state of students, educators, and educational staff, documents related to financing, photos of meetings, and minutes with the madrasah committee.

From the results of the documentation regarding the management of education financing at MTs N 1 Musi Banyuasin, that the madrasah profile contains the identity of the madrasah, explains the vision, mission, and objectives of the madrasah, the organizational structure states the main duties of madrasah administrators, then states the number of students in the last three years., educators and education staff. Then documentation in the form of reports will be used as a reference after supervision by the party in charge of overseeing the use of School Operational Assistance (BOS) funds.

The results of interviews by researchers with madrasah heads and treasurers, and from supporting theoretical data related to supervisory mechanisms are that supervisor activities are activities that aim to reduce or avoid problems related to abuse of authority, leakage and waste of state finances, illegal levies and other forms of fraud.

According to what was said by the head of the madrasah, Ibu Janiah, through interviews with researchers, that the use and management of madrasah financing which is allocated according to the plan is recorded with this port. Furthermore, Pebriyanti, as treasurer, said that madrasahs make a Madrasah Activity and Budget Plan (RKAM) for one year, and prepare reports that have been made in preparation for the examination. From this it is clear that madrasahs must process these funds as professionally as possible. In the supervisory mechanism according to Saefullah [11] that supervision has the following steps: checking, checking, matching, inspecting, controlling, regulating, and preventing before failure occurs.

According to the 2017 edition of the Big Indonesian Dictionary, explaining the meaning of checking, namely the activity of looking carefully to find out the situation (whether or not, wrong, correct, and so on), checking, namely checking whether or not it is true (regarding calculations, lists of numbers, news and so on)matching, namely the activity of comparing to determine whether or not it is suitable (whether or not it is true, etc.), inspecting, namely conducting or conducting an inspection (from time to time), inspection is a thorough examination; official visits to examine whether the rules are being followed, work is being carried out properly, controlling is controlling, holding leadership; govern, regulate, namely make (arrange) something to be orderly (neat), prevent before failure, prevent, namely enforce ;keep things from happening, get in the way; prohibit, make an effort so that it doesn't happen.

Based on the understanding of these supervisory measures and technical guidelines, supervision includes embedded supervision, internal functional supervision, external supervision and community supervision. In more detail, Pebriyanti explained that inherent supervision is the supervision carried out by the head of the madrasah as the power user of the budget, supervision is carried out every month by examining reports on the realization of madrasah financing budget management. 
After the examination was carried out, it was continued to the Musi Banyuasin district state treasury service office to be examined and rechecked the report, after which it was continued to the internal functional supervisor of the district religious ministry, then by the Inspectorate General of the Ministry of Religion of the Republic of Indonesia, which was carried out once a year, Supervision is carried out by checking, checking, checking, if there is a finding of a mismatch in the implementation of budget management, the inspectorate general shall provide directions and guidance to improve the realization of the budget used.

Furthermore, the Financial and Development Supervisory Agency (BPKP), supervision by the BPKP is usually done if the madrasah carries out large amounts of financial development. So, the supervision carried out by the Inspectorate General of the Ministry of Religion of the Republic of Indonesia and the BPKP is to control and prevent before failure occurs. The next supervision is external supervision, which is the supervision carried out by the Supreme Audit Agency (BPK), the supervision is carried out every year, but it depends on which madrasah the agency will supervise (depending on the wishes). Finally, supervision of education financing is carried out by community supervision, namely supervision carried out by the community and public complaint units, such as nongovernmental organizations (NGOs). This institution carries out supervision in the context of photographing the implementation of the BOS program in madrasah, but does not conduct audits.

The researchers concluded that the process of supervising education financing at Madrasah Tsanawiyah (MTs) Negeri 1 Musi Banyuasin was carried out in accordance with the instructions set by the Director General of Islamic Education, namely the management of education financing is supervised by the head of the madrasah, the ministry of religion. district and the inspectorate general of the Republic of Indonesia, BPKP, BPK, and the community.

\section{CONCLUSION}

Based on the results of the research obtained, it can be concluded that the Education Financing Management process at Madrasah Tsanawiyah (MTs) Negeri 1 Musi Banyuasin which is focused on controlling has steps, namely checking, checking, matching, inspecting, controlling, regulating, and preventing before there was a failure. With the supervisory rules in accordance with the technical guidelines for BOS madrasah 2019. The party that carries out the supervision is the head of the madrasah as the inherent supervisor, from the results of the new supervision followed by internal functional supervision by the Inspectorate of the Ministry of Religion, the Provincial Financial and Development Supervisory Agency (BPKP), the Financial Audit Board (BPK) and supervision by the community.

\section{REFERENCES}

[1] Maharani, I., \& Afriansyah, H. (2019). Education Financing Management. In the Journal of the Articles of Padang State University. Accessed from file: //I

$\mathrm{C}$ : /Users/muba/Downloads/Artikel\%20indah\%20mah arani\%20fix.pdf on 14 October 2020.

[2] Nugraha, A., \& Fitria, H. (2019). Infrastructure Management in Improving the Learning Process. In the Proceedings of the National Seminar on Education for the Postgraduate Program at the PGRI University of Palembang. Accessed fromhttps://jurnal.univpgripalembang.ac.id/index.php/Prosidingpps/article/vie w/2515 on 14 October 2020.

[3] Harapan, E. (2018). Educational Financing Theory and Practices Exploring Sources of National Education Financing. Palembang: Noer Fikri.

[4] Handoko, T. H. (2018). Management. Yogyakarta: BPFE.

[5] Matin. (2017). Education Financing Management. Depok: Rajawali Press.

[6] Azhariadi., Harapan, E., \& Fitria, H. (2020). Management of School Operational Assistance (BOS) in SMP Negeri 1 Inderalaya Selatan Kab. Ogan Ilir. In the Light of Education Journal, Vol 6 No.1: 68-79, Master of Education Management, PGRI Palembang University, South Sumatra, Indonesia. Accessed from https://www.journal.unrika.ac.id/index.php/journal cahayapend Pendidikan/issue/iview/249 on 14 October 2020.

[7] Kristiawan, M., Safitri, D., \& Lestari, L. (2017). Education Management. Yogyakarta: Deepublish.

[8] Robbins, S. P., \& Judge, T. A. (2017). Organizational behavior. Jakarta: Four Salemba.

[9] Kartono, K. (2018). Leadership and Leadership: What is Abnormal Leadership? Jakarta: Rajawali Press.

[10] Sagala, S. (2017). Strategic Management in Improving the Quality of Education. Bandung: Alfabeta.

[11] Saefullah, U. (2013). Islamic Education Management. Bandung: Faithful Library.

[12] Mufron, A. (2013). Islamic Education. Yogyakarta: PuraPustaka.

[13] Faijin. (2017). Thesis of Islamic Education Management Study Program, Postgraduate Program of the State College of Islamic Religion of Kudus.

[14] Musfah, J. (2018). Educational Policy Analysis: Non-Creative Education. Jakarta: Prenada media Group. 